\title{
William David Coolidge (1873-1975) Biography with special reference to X-ray tubes
}

\author{
Richard F. Mould
}

William Coolidge (1873-1975) is famous for the invention and development of the hot cathode X-ray tube, sometimes called the Coolidge X-ray tube, which immediately made the previous designs of gas X-ray tube obsolete. He was born in Hudson, Massachusetts, studied at Massachusetts Institute of Technology, and graduated with a PhD in Physics from the University of Leipzig. In 1905 he joined the General Electric Company (GEC) Research Laboratory at Schenectady and in 1913 invented the Coolidge X-ray tube which is the prototype of modern apparatus. He was consultant in X-rays to GEC for some quarter of a century, 1945-1961. As well as his work with X-rays, he developed the first successful submarine detection system, with Irving Langmuir (1881-1957), and during World War II undertook research relating to radar, the atomic bomb, rockets and anti-submarine devices. He was also, during WWII appointed to President Roosevelt's Advisory Committee on Uranium. He obtained 83 patents during his lifetime (all assigned to GEC). Coolidge spent his entire career with GEC, from 1905 when he joined the company at Schenectady to work in lamp research, until his death when he was an Emeritus Director of Research \& Development. One of the most complete lists to be published of papers by Coolidge is found in the References.

NOWOTWORY J Oncol 2017; 67, 4: 273-280

Key words: tungsten, incandescent lamps, gas tubes, hot cathode X-ray tubes, William David Coolidge, Wilhelm Conrad Röntgen, Irving Langmuir, Thomas Edison, Gustav Heinrich Wiedemann, Paul Drude, Arthur Amos Noyes, Willis Rodney Whitney, Edwin Wilbur Rice, General Electric Company, Massachusetts Institute of Technology, Wimshurst electrostatic machine

\section{Introduction}

Today's designs of X-ray tubes can be said to be direct descendants of the original Coolidge X-ray tube which was developed in the 1910 s and which immediately made obsolete the designs of other X-ray tubes, based on the design principle of the pear-shaped gas tube used by Wilhelm Conrad Röntgen (1845-1923) when he discovered X-rays in November 1895. William Coolidge (1873-1975) will forever be famous for his invention, for example for radiotherapy, even in the era of high energy linear accelerators which generate X-ray beams of a few MV, hot cathode tubes are still used for deep X-ray therapy (typical energies 200-300 kVp) and for superficial X-ray therapy (typical energies 60-120 kVp). Neither have they become obsolete in diagnostic radiology in the era of CT scanning and MR scanning. As well as his work with X-rays, he also developed the first successful submarine detection system, with Irving Langmuir (1881-1957), and during World War
II undertook research relating to radar, the atomic bomb, rockets and anti-submarine devices. He obtained 83 patents during his lifetime. Among his many awards and honours were the Rumford Medal of the American Academy of Arts and Sciences (1914), the Hughes Medal of the Royal Society (1927), the Gold Medal of the American College of Radiology (1927) and the Faraday Medal of the Institute of Electrical Engineers, England (1939). Biographies have been written by former employees of GEC, about William Coolidge [1, 2] of which that by Chauncey Guy Suits (1905-1991) [1] gives much family and personal data on Coolidge: as does the biography by Miller [3].

\section{Parents, home \& grade school}

William David Coolidge belonged to the $8^{\text {th }}$ generation of American-born Coolidge family, descended from John and Mary Coolidge who arrived in America in 1630 with Governor John Winthrop and settled in New England. Another 


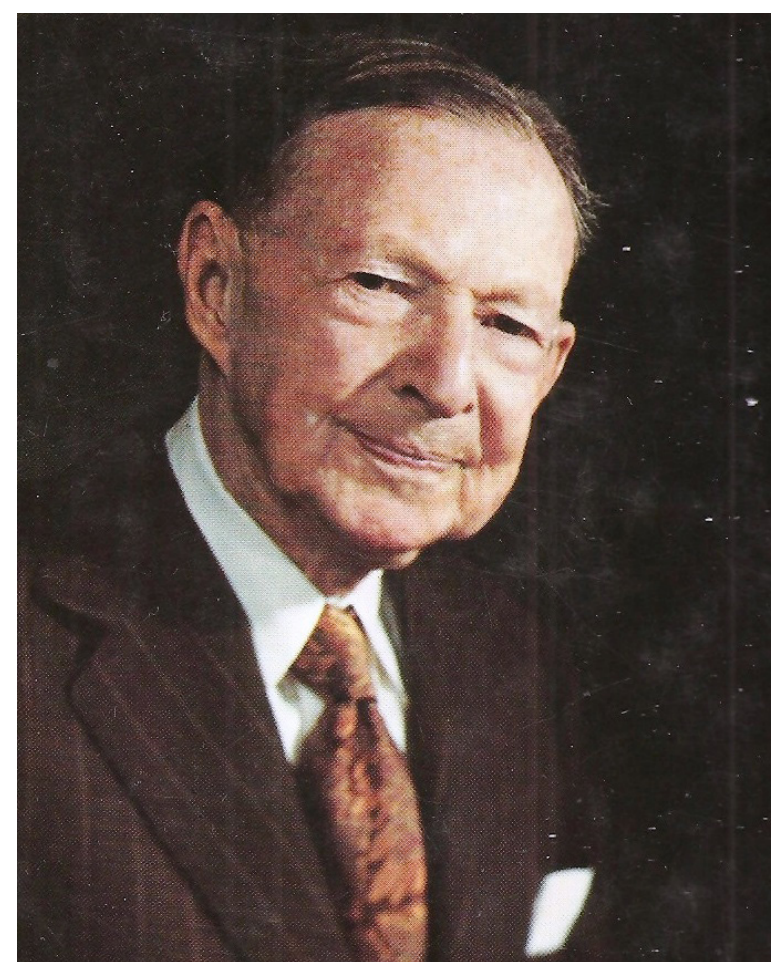

Figure 1. William David Coolidge at age 96 years [2]

Coolidge descendent from John \& Mary was the $30^{\text {th }}$ President of the USA, Calvin Coolidge (1872-1933). John owned 30 acres in Watertown, Massachusetts and was Deputy to the Great \& General Court of the Massachusetts Bay Colony. He had several sons who founded separate branches of the family in New England, mainly near Boston.

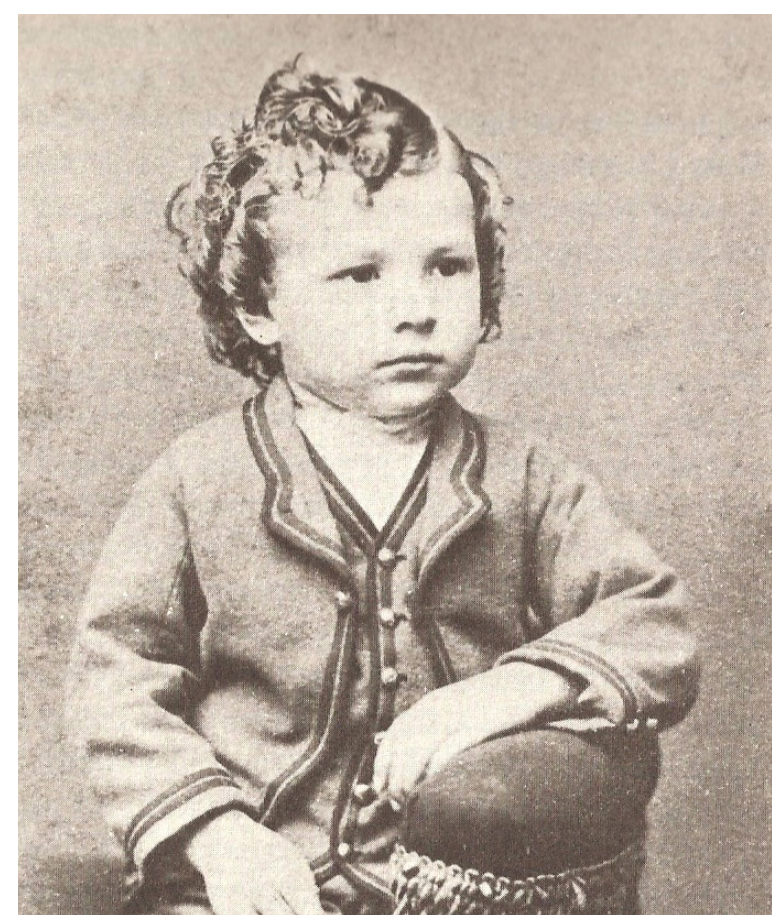

Figure 2. William Coolidge age 5 years [3]
William Coolidge, an only child (Fig. 2) was born in Hudson, Massachusetts, a town of some 3,500 inhabitants about 25 miles west of Boston. His father was a shoemaker and farmer of 7 acres. His mother was a dressmaker. The farm was mostly covered with apple and peach trees with also a vegetable garden. Livestock included a horse, a cow and a flock of chickens. It is recorded [3] that William 'rose at six in the morning in a room which was, in winter, both cold and dark. He dressed by the light of an oil lantern and washed in cold water in the kitchen. After breakfast he walked a mile to the nearest school.' School was primitive: a one-room building catering for six grades and run by only one lady teacher. After school ended each day he had a regular routine of farm chores.

A typical hobby for the boys of the area, including William, was fishing all year, with holes chopped in the ice when it was winter. In addition, for William, photography became a lifelong hobby and during this period he built a basement darkroom in the farmhouse and constructed his own camera, including the shutter. This still left room for baseball, hiking, skating and primitive skiing.

\section{Electric contraptions}

Whilst at grade school he built a contraption that would at a pre-set time, ring an alarm bell, close the open window of his bedroom, and open the door into the hall to admit heat from the warmer part of the house. He also built an electric motor to drive his mother's sewing machine: but unfortunately this never worked [3].

\section{Hudson High School}

After grade school he attended Hudson High School, where he hated elocution so much that his father paid for private tuition. During this time, in order to help with the family finances, he left school for a while and took a job in a local factory, the Apsley Rubber Company. His work initially consisted of folding rubber raincoats for shipment from the factor to retailers and later working as an assistant to the company bookmaker. Perhaps not surprisingly, after a few months he decided to return to High School. He was to graduate Valedictorian in his class of 13 pupils. The subject of his Valedictory discourse was Life is Opportunity.

\section{Massachusetts Institute of Technology, Boston}

Coolidge assumed that because of the limited financial resources of his family he would not be going to college at the end of his final school year. However, this changed when a friend who had been impressed by his scholastic achievements and his mechanical and electrical aptitudes suggested he might be able to obtain a state scholarship to MIT (known at the time as Boston Tech). He successfully applied for a scholarship and in the fall of 1891 started his studies at MIT (Fig. 3). 


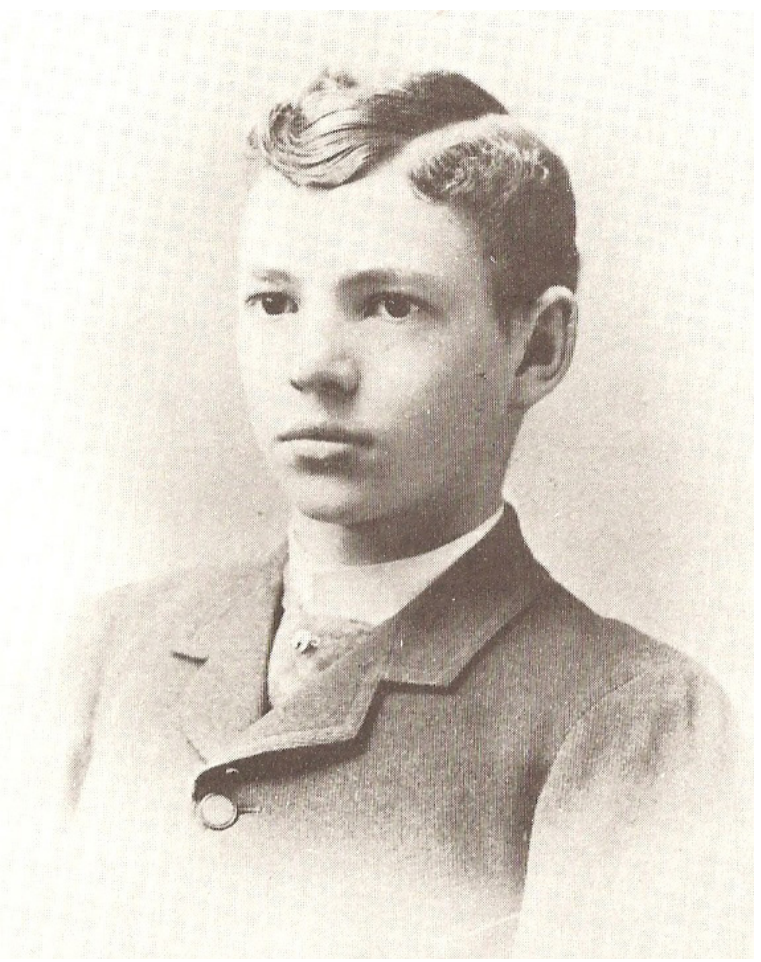

Figure 3. Coolidge in 1891 when he entered MIT [3]

MIT in 1891 consisted of only three buildings accommodating 1,200 students, and offering an engineering degree. At this time only the Military Academy at West Point was the only other institution where an engineering degree could be obtained.

The electrical engineering syllabus taken by Coolidge included some chemistry, mathematics, literature, modern languages and philosophy as well as professional engineering courses. In the chemistry course he was instructed by Willis Rodney Whitney (1868-1958) who was to have a major effect on his future professional life. He spent the summer between his junior and senior years at the East Pittsburgh plant of Westinghouse Electric and gained valuable knowledge of electrical manufacturing processes. Illness kept him out of MIT for a year so he graduated in 1896. In the year following graduation his interests went towards science studies and he took a position at MIT as an Assistant in Physics.

Probably the earliest publication on X-rays from MIT was by Charles Ladd Norton (1870-1939) [4] who in 1893 was a member of the Department of Electrical Engineering \& Physics, becoming an instructor in 1895 and therefore must have been well-known to Coolidge.

\section{X-ray experiments in 1896}

At the time of Röntgen's discovery of X-rays in November 1896, knowledge of which did not reach the U.S.A. till early January 1897. Coolidge was then at MIT where it is known that he experimented with X-rays, although his name did not appear as a co-author on any 1897 X-ray publications. The most important physicists and American universities and colleges involved with X-ray experimentation who published their results in 1896 included Thomas Alva Edison (1847-1931), Arthur Willis Goodspeed (1860-1943) of the University of Pennsylvania, Michael Idvorsky Pupin (1858-1935) of Columbia University, John Trowbridge (1843-1923) of Harvard University and Arthur Williams Wright (136-1915) of Yale University [5].

During the summer of 1896 Coolidge built at home an electrostatic machine with which he made a number of X-ray experiments. Most of the work was done in a small machine shop operated by one of his father's friends in Hudson. He later sold this machine to a local doctor for medical X-ray work [3].

There are now no published records of the equipment design but it was almost certainly what was sometimes termed an influence machine. An 1896 example of such a machine is the Wimshurst (Fig. 4) [6], but there were several other commercial designs made by American companies such as Waite \& Bartlett of New York and Wagner \& Company of Chicago. From the early 1880 s and they were to be found in college, university and school laboratories, well before the discovery of X-rays. The number and sizes of the glass or mica circular plates varied. For example, an 1887 version of the Wimshurst machine had 12 plates each of $30^{\prime \prime}(76 \mathrm{~cm})$ diameter.

\section{General Electric Company}

That G.E. (which was in 1905 to employ Coolidge) experimented with $\mathrm{X}$-rays from the earliest days can be seen from an 1896 publication by the then Technical Director of General Electric, Edwin Wilbur Rice Jr (1862-1935) who was later to become President of G.E. His experimental set-up is shown in Figure $5[7,8]$. He showed a skiagraphy of a purse containing coins and a key. The Wimshurst is shown schematically on the far right of Figure 5 with a spark gap

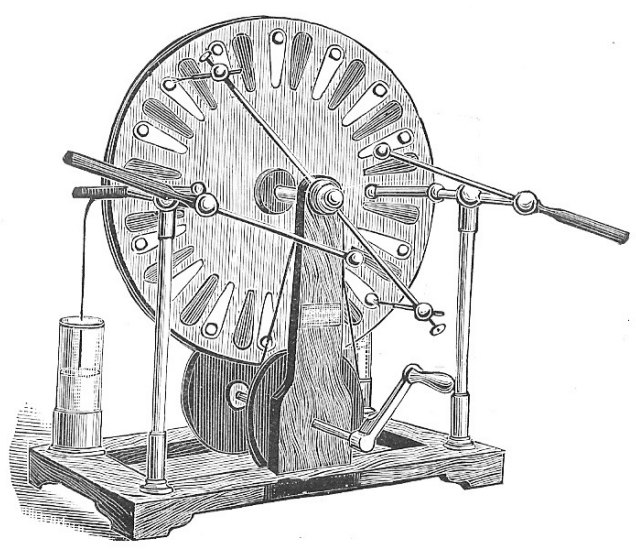

Figure 4. The Wimshurst electrostatic machine [6] 


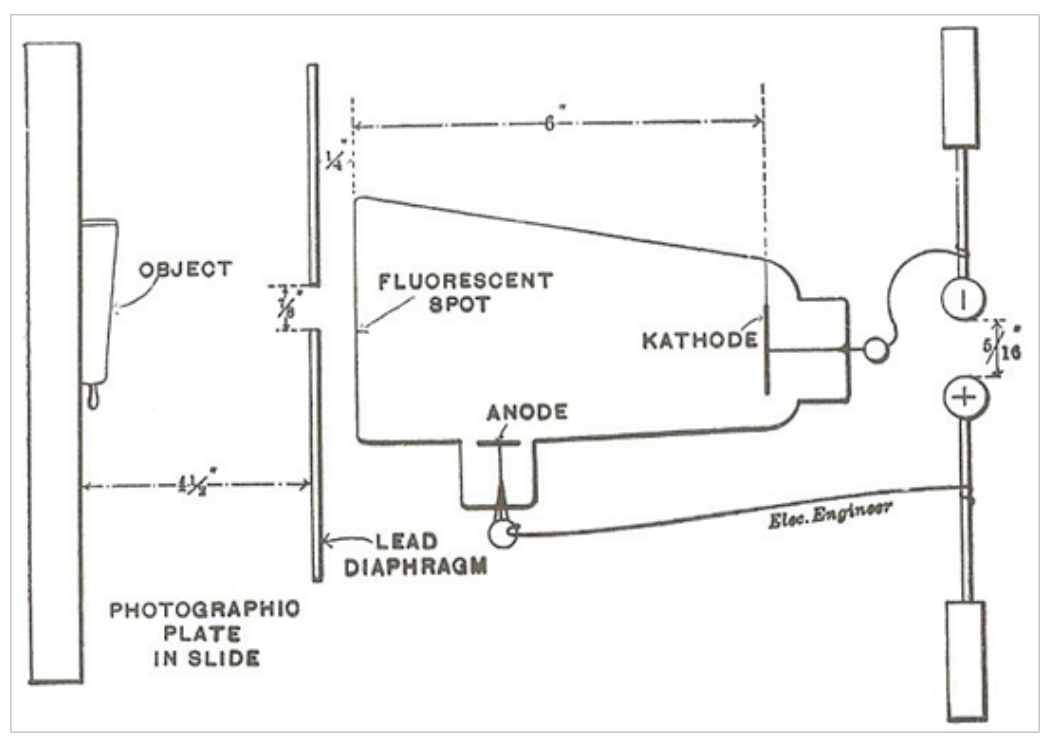

Figure 5. Schematic diagram of Rice's 1896 X-ray experiment $[7,8]$

of 5/16 inches. His reason for publishing this work was his introduction of a lead diaphragm containing a small central opening of $0.875^{\prime \prime}$ diameter, opposite the fluorescent spot. The X-ray image took 60 minutes with this set-up, but only 30 minutes if the diaphragm was removed. However, the diaphragm made the 'shadows' sharper. The X-ray tube was the early pear-shaped design rather than the spherical glass bulb design which was generally adopted by mid-1896.

In addition, Edwin James Houston (1847-1914) and Arthur Edwin Kennelly (1861-1939) who were electrical engineers who formed a consulting company were employed by G.E. in 1896 to provide a review of Edison's experiments, [5, 9].

\section{Leipzig University}

In 1897 Coolidge applied for a grant, for the following year, to undertake graduate work at the University of Leipzig. This was encouraged by Whitney who had also studied in Leipzig. The grant was topped-up by a loan from a friend as it was not sufficient to cover all expenses for this European graduate study. His teachers included the physicist Gustav Heinrich Wiedemann (1826-1899) who is famous for being the editor 1877-1899 of Annalen der Physik \{Wiedemann's Annalen\}, Leipzig; and Paul Drude (1863-1906) a famous optical physicist. Coolidge's first two published papers are to be found in Annalen der Physik und Chemie 1899 [10, 11].

During vacations Coolidge took short trips to Italy and Bavaria, taking photographs which he developed in an improvised darkroom in Leipzig. He also made great efforts to improve his German by talking to Germany students at all opportunities (avoiding English and American students!), attending German church services and living with a Germany family.
In his second year in Leipzig he became Lecture Assistant to Drude. In July 1899 he received high marks in all examinations and was awarded his doctorate summa cum laude. His dissertation was published in Annalen der Physik. During this time, in 1899, Wilhelm Conrad Röntgen (1845-1923) visited the Leipzig Physikalisches Institute, and as Drude's assistant Coolidge was able to meet and talk with the discoverer of $X$-rays. Apparently Coolidge was greatly impressed by this experience [1].

\section{Return to MIT 1899-1905 \& starting work at the General Electric Research Laboratory in Schenectady}

His application to MIT for a teaching position coincided with an opening in the Physics Department for the fall term of 1899 and in 1900 Coolidge became a research assistant to the chemist Arthur Amos Noyes (1866-1936), where he remained for five years $[12,13]$. During this period at MIT he also published work on an apparatus for calibrating voltmeters [14]. Willis Whitney worked in an adjacent laboratory to Noyes at MIT, and he was also commuting to Schenectady during these formative years of the General Electric Research Laboratory which was founded in 1900. Whitney offered Coolidge a job and William started at the GE Research Laboratory in 1905.

\section{Incandescent lamp research}

Whitney had already made improvements in lamp filaments for what was called the GEM lamp, which was about three times more efficient than Thomas Edison's lamp. Research and experimentation on lamps was taking place in both Europe and the USA. For example, the Austrian chemist Carl Auer von 
Welsbach (1858-1929) produced a gas mantle with a filament of osmium. The powdered metal was extruded, then sintered and mounted in the bulb. The resulting lamp worked but was extremely fragile. (The Welsbach Street Lighting Company of America in 1896 installed the first gas lamps with mantles in the USA, in Freehold, New Jersey.) A similar process had been undertaken with tantalum powder, but with the same fragile effect.

Alexander Just (1874-1937) and Franz Hanaman (1878-1941) in Vienna also used a similar process to produce a tungsten filament. These were made by extruding a paste of tungsten powder and a carbonaceous binder to produce a fine thread, then removing the carbon by heating in an atmosphere of hydrogen and water vapour. In 1905 Just \& Hanaman then patented a process for producing tungsten filaments by plating carbon filaments with tungsten, then removing the carbon by heating. However, the problem of brittleness still remained.

These early tungsten lamps were more efficient than those with a carbon filament, because they could operate at a higher temperature, due to the high melting point of tungsten. However, their brittleness meant that they were of limited practical use.

General Electric purchased rights under the Just \& Hanaman patent and Coolidge started working with tungsten (abandoning his previous work with tantalum filaments) and found that sintered filaments of tungsten will lose their brittleness if passed through a rolling mill with heated rollers: a discovery that greatly improved the efficiency of light bulbs. It then took Coolidge some three years of research to develop a process whereby tungsten was made sufficiently ductile at room temperatures to permit drawing through diamond dies. Close control of temperatures, of tungsten powder grain size, and of trace metal additions (particularly thorium) contributed to the final successful result. GE lamps with ductile tungsten filaments appeared on the market in 1911 and have dominated the lighting industry ever since. The technique for producing ductile tungsten filaments passed from the General Electric Research Laboratory into commercial production first at Harrison and then totally at the Cleveland Wire Works (GE as formed in 1892 contained the Edison Lamp Works at Harrison, New Jersey).

The history of incandescent lamps with ductile tungsten filaments can be found in references by Miller [3]. Hirst $[15]$ and Jeffries $[16,17]$. A selection of papers written by Coolidge on ductile tungsten are listed in the References section [18-20] for 1910-1912.

\section{Roentgen ray research: X-ray tubes}

Coolidge first published on Roentgen ray research in March 1912 [21] but it was not until 1913 that the so-called hot cathode $X$-ray tube, also called the Coolidge X-ray tube, was to become available commercially. Until this time the standard X-ray tube worldwide was the gas tube, and more than 100 designs were made. The pear-shaped glass bulb version was used by Wilhelm Conrad Röntgen (1845-1923) when he discovered X-rays in 1895. This was sometimes termed a Crookes' tube after Sir William Crookes (1832-1919). However, the bulb shape was rapidly changed to become spherical and two major improvements were made by incorporating a metal target and a concave-shaped cathode, the focus $X$-ray tube. Figure 6 is a schematic diagram of the original pear-shaped $\mathrm{X}$-ray tube.

The glass envelope is airtight and has two electrodes sealed into it. The tube is evacuated to a low pressure with some gas molecules remaining (hence the name gas tube). The electric discharge when a high voltage is applied between the electrodes causes ionisation of the gas atoms, and the positive ions are driven towards the cathode by the electric potential across the tube. The bombardment of the cathode by these positive ions causes emission of electrons which on striking the target (which in Figure 6 is the large end of the glass wall of the tube) generate X-rays. There were many problems with these gas tubes, which

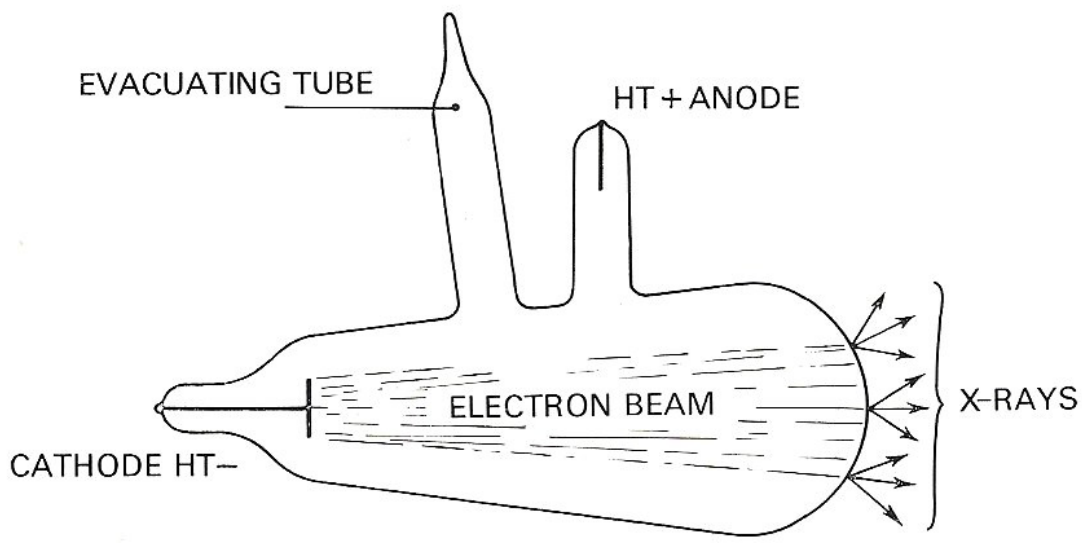

Figure 6. A gas X-ray tube [22] 


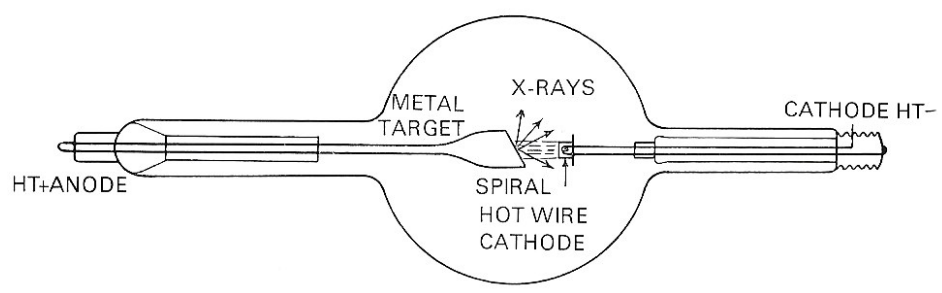

Figure 7. Coolidge X-ray tube [22]

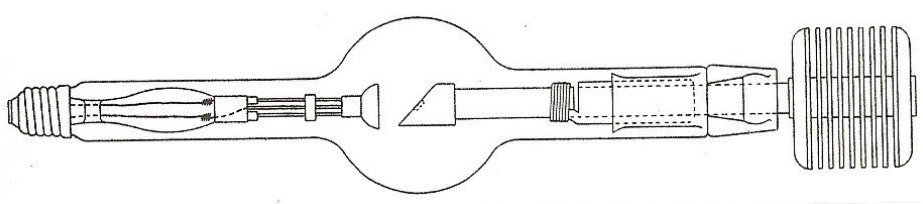

Figure 8. Radiator-type Coolidge X-ray tube [29]

were of very low power and could not produce high energy hard X-rays. Exposure times were lengthy, targets became overheated and tubes often did not last too long because they became punctured. Improvements in X-ray tubes for diagnosis and therapy were therefore badly needed and this need was filled by the hot cathode tube developed by William Coolidge. It became so successful that the gas tube soon became obsolete. Figure 7 is a schematic diagrams of a Coolidge tube such as was available in 1914 [23].

One of the disadvantages of the gas tube was the variation in the degree of the vacuum over a period of time. In the gas tube a reduction in gas pressure leads to a higher operating voltage and hence more penetrating (termed harder) X-rays. However, because there is less gas in the tube, the current falls and the intensity of the $X$-ray beam is reduced This is because the voltage across the tube and the current through it are inter-dependent.

In the X-ray tube produced by Coolidge the vacuum is as near perfect as possible and the electrons are produced by thermionic emission. The cathode is no longer a cold metal block (as in the later designs of gas tube), but a tungsten filament heated to incandescence by a current passing through it. The filament is usually mounted within, and electrically connected to, a shaped metal block which focusses the electrons on to the target. The intensity of the X-ray output depends only on the current in the electron beam, which is a function of the temperature of the filament. This can be controlled by adjusting the current in the filament. Thus with the Coolidge hot cathode X-ray tube the intensity and penetration of the X-ray output are independently controlled by adjustment of the filament current and tube voltage, respectively.

Coolidge continued to publish on hot cathode X-rays tubes after 1914, both original work and reviews, in 1915 [24-26], in 1917 [27, 28], in 1918 [29, 30]. A schematic diagram of a radiator type X-ray tube [29] is shown in Figure 7. It was built with a copper-backed tungsten target that operates over a wide range of energy ratings and which is capable of rectifying its own current. Many more published papers followed from 1919-onwards [31-84].

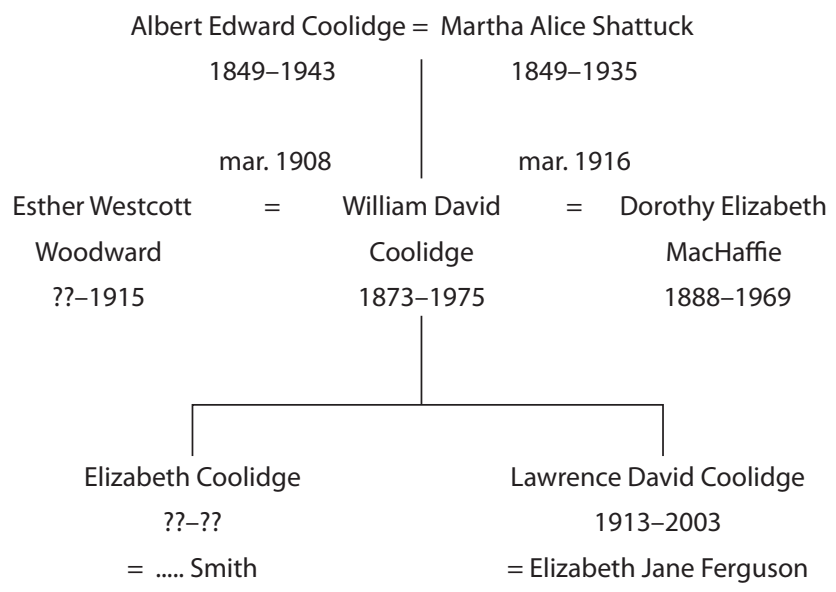




\section{Marriages}

William had two children from his first marriage, his wife, Esther, dying at a young age. His son, Lawrence, who was a United States Army World War II veteran, obtained a PhD in 1950 from Columbia University and ended his professional career as Dean of the School of Business, University of Colorado at Boulder. His second wife, Dorothy, was a nurse whom he had employed to help his mother look after his two children, following his wife's death. They married within the year. There were no children from this marriage.

\section{Richard F. Mould, MSc, PhD}

\section{4, Town End Meadow}

Cartmel

Grange-over-Sands

Cumbria LA1 6QG

United Kingdom

e-mail:manorroadsouthport@yahoo.co.uk

\section{References}

1. Suits CG. William David Coolidge 1873-1975 A Biographical Memoir. Washington DC: National Academy of Sciences, 1982. [On 1 January 1945 Suits succeeded Coolidge as Director of the GE Research Laboratory].

2. Liebhafsky HA. William David Coolidge: a Centenarian and His Work. New York: Wiley, 1974. [Liebhafsky was an Executive Engineer in the GE Research Laboratory 1912-1945].

3. Miller JA. William David Coolidge Yankee Scientist. Schenectady: Mohawk Development Service, 1963.

4. Norton CL. X-rays in medicine and surgery. Science 15 May 1896; 3: 231.

5. Mould RF. Annotated X-Ray Bibliography 1896-1945. Warsaw: Polish Oncological Society, 2014.

6. Ward HS. Practical Radiography: a Handbook of the Applications of the X-rays. London: Dawbarn \& Ward, published for The Photogram magazine, 1896.

7. Rice EW. Producing Röntgen rays under novel conditions. Electrical Engineer [New York] 22 April 1896; 21: 401.

8. Thompson EP. Roentgen Rays and Phenomena of the Anode and Cathode. [Descriptions of experiments and reviews published on X-rays in 1896. This is the first published X-ray bibliography] Experiment 101; New York: Van Nostrand, 1896.

9. Houston EJ, Kennelly AE. Edison's Röntgen ray experiments. Electrical Engineer [New York] 18 March 1896; 21: 281.

10. Coolidge WD. Eine neue method zur demonstration der elektrichen drahtwellen. Annalen der Physik und Chemie 1899; Neue folge 67: 578-591.

11. Coolidge WD. Untersuchungen und elektrische drahtwellen. Annalen der Physik und Chemie 1899; Neue folge 69: 125-166.

12. Coolidge WD, Noyes AA. Electrical conductivity of aqueous solutions at high temperatures. Proc Am Acad Arts \& Sciences 1903; 39: 163-219.

13. Coolidge WD, Noyes AA. The electrical conductivity of aqueous solutions. II. Original apparatus and method. Conductivity and ionization of $\mathrm{NaCl}$ and $\mathrm{KCl}$ up to 306 degrees. Carnegie Institute Washington Publication 1908; 63: 9-55. \& III. The electrical conductivity of aqueous solutions. 1908; 63: 59-67.

14. Coolidge WD, Laws FA. Apparatus for rapidly calibrating voltmeters. Technology Quarterly 1902; 15: 69-73.

15. Hirst H. Recent progress in tungsten metallic filament lamps. The Electrical Journal 1908; 61: 215-216.

16. Jeffries Z. The metallography of tungsten. Trans Am Inst Mech Eng 1919; 60: 588. [Jeffries was employed by the Cleveland Wire Works].

17. Jeffries Z, Tarasov P. Tungsten and thoria. Proc Inst Met Div Trans Inst Mech Eng 1927; 77a: 395.

18. CoolidgeWD. Ductile tungsten. Trans Am InstElec Eng 1910;29:961-965.

19. Coolidge WD, Howell J, Scott CF. Ductile tungsten and metal-filament electric lamps. Engineering News 1910; 64: 7-9.

20. Coolidge WD. Some applications of wrought tungsten and molybdenum. J Industrial \& Engineering Chemistry 1912; 4: 2-4.

21. CoolidgeWD. Roentgen ray research. The use of tungsten for the target. Metallurgical and Chemical Engineering 1912; 10: 146.

22. Bowers B. X-Rays. Science Museum Booklet. London: HMSO, 1970.
23. Coolidge WD. A powerful Roentgen ray tube with a pure electron discharge. Phys Rev $2^{\text {nd }}$ series 1913; 6: 409-430. Abstracts in the Am J Roentgenol 1914; 1: 115-124. General Electric Rev 1914; 17: 104-111. Elec World 1914; 63: 220-221.

24. Coolidge WD. Hard X-rays. Am J Roentgenol 1915; 2: 723-725.

25. CoolidgeWD. A summary of physical investigation work in progress on tubes and accessories. Am J Roentgenol 1915; 2: 881-892.

26. Coolidge WD. Roentgen's discovery. Its recent development and future possibilities. New York Med J 1915.

27. Coolidge WD. Physical investigation work in progress on tubes and accessories. Am J Roentgenol 1917; 2: 55-65.

28. CoolidgeWD, Moore CN. Roentgen rays from sources other than the focal spot tubes of the pure electron discharge type. General Electric Review 1917; 20: 272-281. Archives Radiol \& Electrotherapy 1917; 22: 216-221.

29. Coolidge WD. A new radiator type of hot-cathode Roentgen-ray tube. General Electric Review 1918; 21: 56-60.

30. Coolidge WD. A portable Roentgen-ray generating outfit. General Electric Review 1918; 21: 60-67.

31. Coolidge WD. The radiation type of (X-ray) tube. Am J Roentgenol 1919; 6:175-179.

32. Coolidge WD. Apparatus for portable radiography. J Roentgenol 1919; 2: $149-176$.

33. Coolidge WD. Oil-immersed X-ray generating outfits. Am J Roentgenol 1920; 7: 181-190.

34. Coolidge WD. A portable X-ray outfit. Elec World 1920; 75: 981.

35. Coolidge WD. Tungsten and the Coolidge X-ray bulbs. Engineering 1920; 110: 109-110.

36. Coolidge WD. X-ray work at Schenectady. J Roentgen Soc [London] 1921; 17: 23-29.

37. Coolidge WD. The Kearsley stabilizer. Am J Roentgenol 1921; 8: 599-602.

38. Coolidge WD, Kearsley WK. High voltage X-ray work. Am J Roentgenol 1922; 9: 77-101.

39. Coolidge WD. The production of X-rays at short wavelength. Albany Med Annals 1922.

40. Coolidge WD, Moore CN. A water-cooled high voltage X-ray tube. Am J Roentgenol \& Radium Therapy 1923; 10: 884-890.

41. Coolidge WD, Moore CN. The operation of X-ray tubes at high voltages. J Radiol 1924; 5: 9-12.

42. Coolidge WD. Oil-immersed X-ray generating outfits and their uses. J Optical Soc America \& Rev Sci Instruments 1924; 9: 653-673. General Electric Review 1925; 26: 182-192.

43. Coolidge WD. Modern X-ray tube development. J Franklin Inst 1925; 199: 619-648.

44. Coolidge WD. High-voltage cathode rays outside the generating tube. Science 1925; 62: 441-442.

45. Coolidge WD. The production of high-voltage cathode rays outside of the generating tube. J Franklin Inst 1926; 202: 693-721.

46. Coolidge WD, Moore CN. Some experiments with high-voltage cathode rays outside of the generating tube. J Franklin Inst 1926; 202: 721-734.

47. Coolidge WD, Knudson A. Effect of high-voltage cathode rays on rickets and on the activation of cholesterol. Proc Soc Experimental Biology \& Medicine 1927; 24: 366-369.

48. Coolidge WD. Some past developments and future possibilities in very high-voltage vacuum tubes. General Electric Review 1928; 31: 184-185.

49. Coolidge WD. Cathode-ray and Roentgen-ray work in progress. Am J Roentgenol \& Radium Therapy 1928; 19: 313-321.

50. CoolidgeWD. The development of modern X-ray generating apparatus. General Electric Review 1930; 33: 608-614 \& 723-726.

51. Coolidge WD. The development of modern Roentgen-ray generating apparatus. Am J Roentgenol \& Radium Therapy 1930; 24: 605-620.

52. Coolidge WD. Hickey the scientist. Am J Roentgenol \& Radium Therapy 1931; 25: 170-171.

53. Coolidge WD, Dempster LE, Tanis HE. High-voltage cathode ray and X-ray tubes and their operation. Physics 1931; 1: 230-244.

54. Coolidge WD, Dempster LE, Tanis HE. A high-voltage induction coil and cascade tube Roentgen-ray outfit. Am J Roentgenol \& Radium Therapy 1932; 27: 495-514.

55. Coolidge WD, Charlton EE. Modern X-ray tubes. Congress Int d'Electricite, Paris, 1932; Section 10, Report 2.

56. Coolidge WD, Moore CN. Experimental studies of cathode rays outside of the generating tube. Congress Int d'Electricite, Paris, 1932; Section 1, Report 19. \& General Electric Review 1932; 35: 413-417.

57. Coolidge WD et al. Symposium on some activities of the Research Laboratory of the General Electric Company. Discussion on X-ray tubes. Trans Am Inst Chemical Engineers 1933; 28: 31-55.

58. Coolidge WD, Charlton EE. Roentgen-ray tubes. In: Glasser O, (ed.). The Science of Radiology, 1933; London: Bailliere Tindall \& Cox, 1933, 77-95. 
[Seven of Coolidge's patents are quoted by him in this 1933 reference. 1913. Ductile tungsten (tungsten and method of making the same as use for filaments of incandescent lamps and for other purposes) U.S. Patent 1082933. 1915. Method of making composite metal bodies. U.S. Patent 1162339. 1917, X-ray tubes. (an air-cooled tube with a solid tungsten target used for diagnosis and therapy) U.S. Patent 1211092. 1917 , X-ray apparatus (rotating tube). U.S. Patent 1215116. 1922. X-ray tube shields. U.S. Patent 1437290. 1924, X-ray devices (portable X-ray tube). U.S. Patent 1502907. 1933. X-ray tubes. (including a special tube for internal body cavity work) U.S. Patent 1917099].

59. Coolidge WD, Charlton EE. Gas-free metals used in X-ray tubes. Metal Progress 1933; 24: 36-40.

60. Coolidge WD. Acceptance address of the award of Gold Medal by the American Institute of the city of New York to the General Electric Company. General Electric Review 1934; 37.

61. Coolidge WD. Scientific developments and their application. Scientific Monthly 1934; 38: 307.

62. Coolidge WD. Research as a career. Technology Rev 1934; 36: 341

63. Coolidge WD. Presentation of the Comstock Prize of the National Academy of Sciences to Dr. Ernest Orlando Lawrence. Science 1937; 86.

64. Coolidge WD. Research in a large industry. Armour Engineer \& Alumnus 1937; 3.

65. Coolidge WD. The production of X-rays of very short wavelength. Radiology 1938; 30.

66. CoolidgeWD. Contribution of physics to cancer therapy. (Dedication of new building and equipment, Memorial Hospital, New York). General Electric Review 1939; 42.

67. Coolidge WD. Elihu Thomson's interest in research. Science 1939; 89.

68. Coolidge WD. Faraday Medical acceptance address. Electrical Engineer 1939; 58. \& General Electric Review 1939; 42.
69. Coolidge WD. X-rays then and now. Albany Medical Annals 1939; 58.

70. Coolidge WD. Radiation therapy. Radiology 1940; 34.

71. CoolidgeWD. Research and invention. (presented before the U.S. Temporary National Economic Committee, Congress of the United States, $1^{\text {st }}$ session) Government Printing Office 1940

72. Coolidge WD. The Research Laboratory of the General Electric Company Science 1940; 92.

73. Coolidge WD. Seventy years of physical science. Popular Science Monthly 1942; 140

74. Coolidge WD. The role of science institutions in our civilization. Science 1942; 96.

75. Coolidge WD. Response to accepting the Dudell medal at the meeting of the American Physical Society. J Applied Physics 1943; 13.

76. CoolidgeWD. Peacetime salvage from wartime research. Address given before the Dental Society of the State of New York. 1943.

77. Coolidge WD. The rapidly expanding field of usefulness of X-rays. J Franklin Inst 1944; 237.

78. Coolidge WD, Atlee ZJ. Roentgen rays: tubes. In:Medical Physics, Glasser O (ed), Chicago, 1944.

79. Coolidge WD, Charlton EE. Roentgen-ray tubes. Radiology 1945; 45

80. CoolidgeWD. Experiences with the Roentgen-ray tube. Am J Roentgenol \& Radium Therapy $1945 ; 54$.

81. Coolidge WD. Highlights of the past and a challenge for the future. X-Ray Technician 1949; 20

82. Coolidge WD. My early work in tungsten. Remarks on receiving the Li medal. 1952.

83. Coolidge WD. A plea for more fundamental research effort. Science 1945; 119: 110-111.

84. Coolidge WD. A half-century's development of X-ray generators. Am J Roentgenol \& Radium Therapy 1956; 75 